\title{
Juvenile mortality in benthic marine invertebrates
}

\author{
Louis A. Gosselin*, Pei-Yuan Qian
}

Department of Biology, Hong Kong University of Science and Technology, Clear Water Bay, Kowloon, Hong Kong

\begin{abstract}
Thirty years ago, Thorson (1966; Neth J Sea Res 3:267-293) calculated that juvenile mortality in marine bivalves could exceed $98.6 \%$. Subsequently, juvenile mortality rates have been assumed to be high and to influence the evolution of life history traits. However, there have been no attempts to establish whether high juvenile mortality is common or to determine if interspecific trends in juvenile mortality exist. To address this issue, we reviewed 30 studies of age-specific mortality among bivalves, gastropods, barnacles, ascidians, bryozoans and echinoderms. High juvenile mortality is widespread among benthic marine invertebrates, with 20 of the 30 studies reporting levels of juvenile mortality $>90 \%$. Mortality is particularly high during the first moments of juvenile life, and can exceed $30 \%$ during the first day. Pooling survivorship data from all species revealed a general trend, with survivorship decreasing exponentially during the first days or weeks of juvenile life until, by the age of $4 \mathrm{mo}$, virtually all cohorts were reduced to $<20 \%$ of their initial numbers; mortality remained low thereafter. We suggest that extreme vulnerability at the onset of juvenile life is a shared trait that is largely responsible for the survivorship trend. Natural variation within this trend would be largely due to variation in intensity of mortality factors. Predation and desiccation are well-documented causes of juvenile mortality, but the current lack of data on factors such as ultraviolet radiation, diseases, and 'internal' causes (energy depletion, developmental and physiological defects) precludes a ranking of factors as selective pressures. Methods used to quantify juvenile mortality vary considerably in the level of resolution they can achieve within the early juvenile period. Studies of early juvenile mortality should ideally monitor the fate of individuals from the onset of juvenile life, using sampling intervals $\leq 1 \mathrm{~d}$. Mapping and imaging techniques can provide accurate results for sessile organisms, whereas mark and recapture can be effective for motile animals with limited dispersal. Early juvenile mortality has been shown to influence population abundance and distribution as well as community structure. Juvenile mortality is also expected to be an important determinant of age at maturity, but only among species maturing within 4 mo of postlarval life since mortality remains low after the age of $4 \mathrm{mo}$. A compilation of data on age at first reproduction in 92 species revealed a bimodal grouping of species: $22 \%$ of species maturing within $45 \mathrm{~d}$ after beginning juvenile life, and $60 \%$ maturing after at least 1 yr The influence of juvenile mortality on age at maturity will differ substantially among these 2 groups and will therefore not be equal or directly comparable among all species. Given the magnitude of early juvenile mortality and the similarities in mortality patterns across diverse taxa and habitats, a better understanding of early juvenile mortality should help researchers to understand how population parameters are regulated and help elucidate the significance of traits that characterize populations and species.
\end{abstract}

KEY WORDS: Mortality factors - Survivorship - Early juvenile - Selective pressures · Population parameters Life history traits . Age at maturity

\section{INTRODUCTION}

In a seminal paper published 3 decades ago, Thorson (1966) suggested that mortality rates could be high among newly established juvenile invertebrates. He calculated that less than $1.4 \%$ of bivalves settling on

•E-mail: lgosseli@usthk.ust.hk subtidal mudflats might survive long enough to reach a size of $2 \mathrm{~mm}$. At this level of mortality, the processes responsible for mortality during juvenile life could have major repercussions on population parameters such as abundance and distribution. High juvenile mortality could also constitute a driving force in the evolutionary development of a species, as postulated in models linking age at first reproduction (e.g. Stearns 


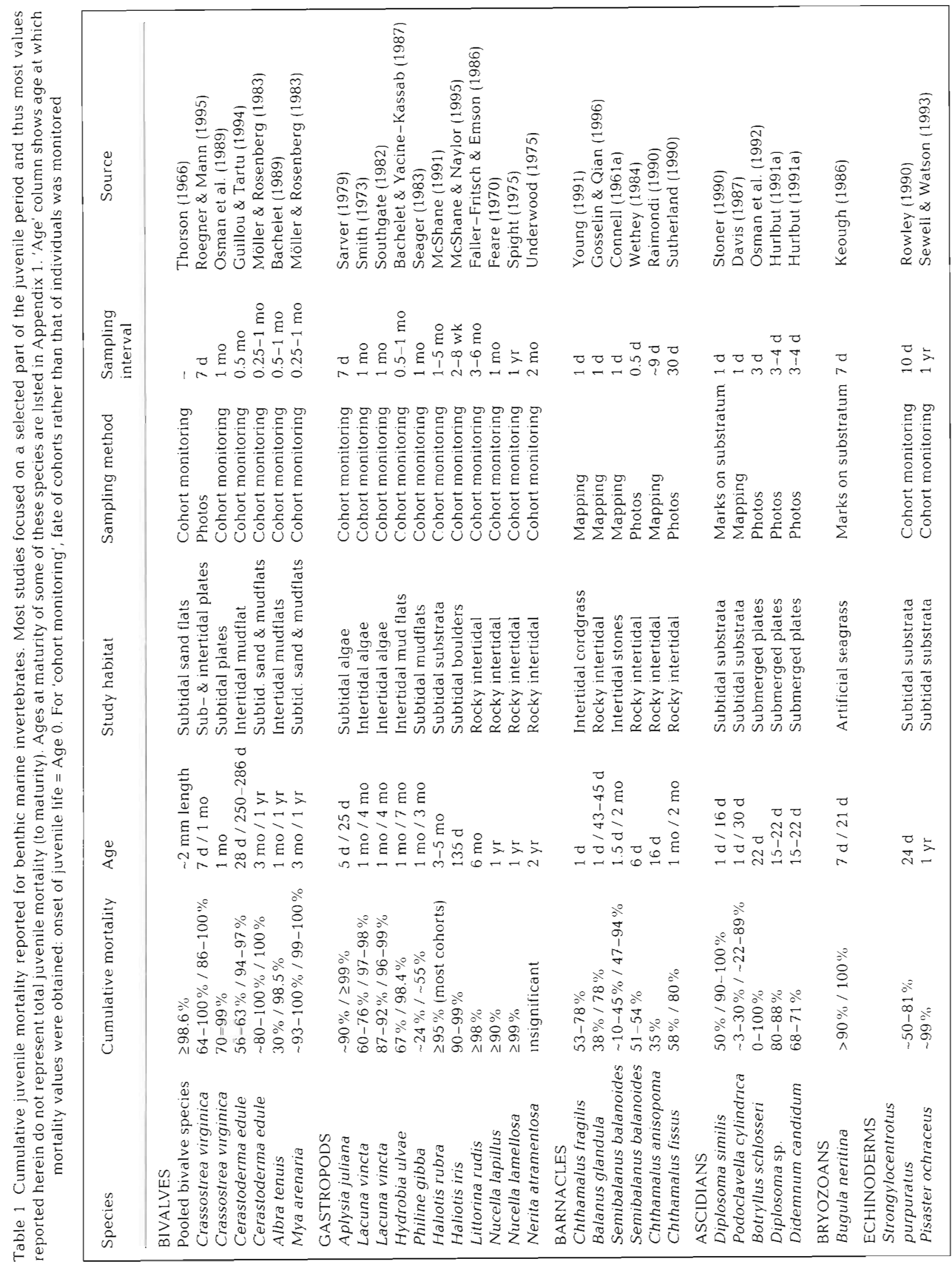


\& Koella 1986) with levels of juvenile mortality. But while high juvenile mortality has been reported, there have been no attempts to establish whether high juvenile mortality is common or to identify interspecific trends in juvenile mortality.

Since Thorson's study, new information on the ecology of juveniles has revealed that the processes operating during the early part of juvenile life differ from those operating at any other time of life. Werner \& Gilliam (1984), for instance, found that many aquatic animals shifted their diet and habitat use at some point during the juvenile period. More recently, detailed studies of early juvenile lobsters (Homarus americanus, Wahle \& Steneck 1991, Cobb \& Wahle 1994; Panulirus argus, Smith \& Herrnkind 1992) and snails (Nucella emarginata, Gosselin 1994) have shown early juveniles to be ecologically distinct from late juveniles and adults. Early juveniles differed from individuals at other periods of life in their use of microhabitat and food resources and in vulnerability to mortality factors. Available information for other benthic invertebrates suggests the early juvenile period is an ecologically distinct phase in many species, particularly those with motile juveniles (cf. Gosselin 1994). The patterns and the effects of juvenile mortality would therefore be regulated at least in part by processes that are specific to the early juvenile period.

In this paper, we examine the significance of juvenile mortality for benthic marine invertebrates by reviewing published reports of natural levels and causes of juvenile mortality and its implications for population parameters and 1 life history trait. Given that a variety of approaches have been used to quantify juvenile mortality, we also document the uses and limitations of the most commonly employed methods. The specific objectives of this paper are to (1) document the natural levels of juvenile mortality and identify interspecific trends among benthic invertebrates, (2) critically review the methods used to quantify natural juvenile mortality, (3) identify the causes of juvenile mortality, and (4) examine the implications of juvenile mortality for population parameters and age at maturity.

\section{CONTEXT AND FOCUS}

We review 30 studies reporting age-specific mortality data for at least the early period of juvenile life in natural or near-natural field conditions. The resolution of these studies varies widely, from rough estimates based on 'snap-shot' samples to precise survivorship curves starting at the onset of independent benthic life. There is also considerable variation in the duration of the studies. Finally, biological differences add to the complexity of the analysis, particularly differences in duration of the juvenile period among taxa. For instance, the first 2 mo after settlement constitute only a small portion of juvenile life in the seastar Pisaster ochraceus, which matures $\sim 5$ yr after settlement (Menge 1974), but 2 mo are sufficient for newly settled ascidians Didemnum candidum to reach maturity and release gametes (Hurlbut 1991a). Although direct comparisons of results from different studies are limited by these circumstances, the data are nevertheless amenable to a broader investigation of mortality patterns among benthic invertebrates, on which the present review will focus

\section{MAGNITUDE AND TIMING OF JUVENILE MORTALITY}

Levels of juvenile mortality exceeding $90 \%$ were reported in 20 of the 30 papers reviewed herein and were observed in bivalves, gastropods, barnacles, ascidians, bryozoans and echinoderms (Table 1). Seventeen studies report cases of juvenile mortality $\geq 98 \%$.

Of particular interest is the high mortality observed immediately after settlement in 3 barnacles and 2 ascidians (Table 1). In all 5 species, cases of mortality $\geq 30 \%$ were recorded during the first 1 to $1.5 \mathrm{~d}$ after settlement. The highest first-day mortality was reported for Chthamalus fragilis (Young 1991): 53 to $78 \%$ of individuals settling on the cordgrass Spartina alterniflora did not survive the first day in their new habitat. In an elegant study, Stoner (1990) directly observed the release, dispersal and settlement of individual Diplosoma similis larvae on natural substrata in the field and then monitored their fate on a daily basis for the following $26 \mathrm{~d}$ : $50 \%$ of these settlers died during the first day after settlement. In newly settled Balanus glandula, 38\% died during the first day after settlement (Gosselin \& Qian 1996). Mortality rates in D. similis and $B$. glandula dropped sharply after the first day, indicating that a brief initial period as short as $24 \mathrm{~h}$ following the transition to independent benthic life can be a critical period for survival.

To verify the existence of general patterns in juvenile mortality, a survivorship curve was produced by pooling data from all the studies listed in Table 1 . The resulting graph, which presents data for the juvenile period only, reveals a clear interspecific trend of survival as a function of age (Fig. 1). Survivorship decreased exponentially during the first days or weeks of juvenile life, and by the age of 4 mo virtually all cohorts were reduced to $\leq 20 \%$ of their initial numbers. This trend might be partly due to a methodological bias (e.g. there is less data for the 2 to 12 mo age interval than for the first $2 \mathrm{mo}$ ). However, the coherence of the 

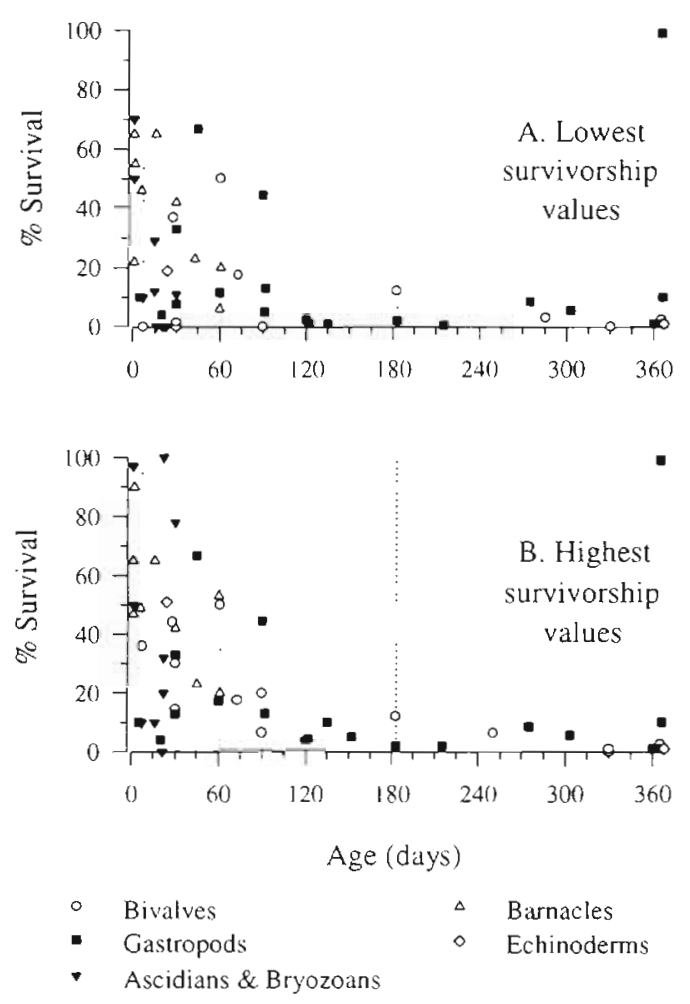

Fig. 1. Survivorship of benthic marine invertebrates during the juvenile period. Age $=0$ corresponds to the onset of juvenile life. All data plotted herein were extracted from the 30 studies listed in Table 1 To integrate these results into a single figure, 4 age intervals (delimited by dashed vertical lines at ages $=7,61$, and $183 \mathrm{~d}$ ) were subjectively determined based on age periods for which most data were available. Each study contributed a maximum of 4 data points to the figure, 1 point per age interval. Since several studies report mortality or survivorship data as a range, and occasionally for a range of ages, the data are represented in 2 graphs: (A) displays the lowest survivorship values (highest mortality, shortest age interval) reported in each study, (B) displays the highest survivorship values

data contrasts with the diversity of methods and sampling intervals, suggesting that the pattern is not a methodological artifact. We conclude that high mortality shortly after the onset of juvenile life is a common occurrence among benthic invertebrates

The existence of this common trend in juvenile mortality is fascinating, as it suggests that juvenile survivorship across taxa and habitats could be regulated by a common set of processes. Since the intensity of most mortality factors differs widely among habitats, the trend is unlikely to be attributable to similarities in causes of death. Rather, the more basic issue of vulnerability could be the unifying element. The initial sharp decline in mortality rates over the first 1 to $2 \mathrm{~d}$ may result from rapid anatomical, physiological, and possibly behavioural changes at the start of juvenile life, allowing the young individual to cope with the new environment it then faces (Gosselin \& Qian 1996). Individuals generally begin juvenile life with minimal or incomplete protective structures, such as shell, carapace, or tegument. In addition, changes in mortality rates during the first hours or days may be due to a rapid elimination of individuals located in unfavourable sites. Beyond the first days of juvenile life, mortality rates could be largely dependent on body size, a major determinant of vulnerability. Growth could therefore be responsible for much of the common trend in juvenile mortality since most species begin juvenile life as meiofauna. The gradual levelling of $f$ of survivorship would be a result of the juveniles reaching critical sizes at which vulnerability to physical and biological constraints is substantially reduced (e.g. Wahle \& Steneck 1992, Gosselin 1994).

Although the data in Fig. 1 reveal an upper limit to juvenile survivorship, mortality levels varied within this trend. Methodological differences undoubtedly account for part of this variation, but in many field studies substantial variation was also common among replicates for a given species, indicating that spatial and temporal variation in natural mortality is often important. Variation in intensity of mortality factors is likely to be a major cause of this natural variation in mortality. This hypothesis is supported by data linking variation in juvenile mortality to tidal height (Roegner \& Mann 1995), habitat (Davis 1987, Osman et al. 1989, Rowley 1990, Young 1991), and season (Grosberg 1988, Roegner \& Mann 1995). In addition, the occurrence of either dominant or very small year classes in benthic populations has been attributed to unusually benign or harsh conditions at the time of early juvenile development (Connell 1961a, MacKenzie et al. 1985, Sebens \& Lewis 1985).

Data for 3 species did not conform to the general trend (Table 1, Fig. 1). Mortality of the gastropod Nerita atramentosa was reported to be insignificant during the first 2 yr after settlement (Underwood 1975), whereas in the antarctic opisthobranch Philine gibba $-45 \%$ would survive to the age of 3 mo (Seager 1983). In a third species, the bivalve Albra tenuis, $50 \%$ and $24 \%$ of individuals were reported to survive the first 2 and $4 \mathrm{mo}$, respectively (Bachelet 1989), values that are somewhat above the general trend. These 3 reports, however, were based on cohort studies with long sampling intervals (Table 1), a methodology that does not reliably quantify mortality during the first weeks of juvenile life (see 'Cohort monitoring'). It is therefore possible that even these species conform to the pattern of high early mortality. Nevertheless, the prospect that a few species may achieve high survivorship during the early juvenile period is intriguing, as this suggests outcomes other than high early mortality are possible. 


\section{METHODS FOR QUANTIFYING EARLY JUVENILE MORTALITY}

The accurate determination of the timing (relative to age) and magnitude of mortality are necessary to correctly assess when selective pressures are most intense and to accurately quantify their effect. The pattern of mortality plotted in Fig. 1 therefore has 2 methodological implications for studies of juvenile mortality. First, studies that do not quantify mortality from the onset of juvenile life may significantly underestimate juvenile mortality, miss critical events that impact population parameters, and incorrectly estimate the relative importance of larval and postlarval processes. Of the 30 studies listed in Table 1 only $6(21 \%)$ quantified mortality from the onset ( first $24 \mathrm{~h}$ ) of juvenile life; most juvenile mortality data may therefore be underestimates.

Secondly, since the early period of high mortality may last from a few days to up to $4 \mathrm{mo}$, a detailed survivorship curve is necessary to determine when the most intense selective pressures are in effect. The degree to which this second goal is reached is directly linked to sampling frequency. By increasing sampling frequency during the early juvenile period (e.g. to daily, tidally or hourly sampling), the resolution of the survivorship curve is improved, up to the point where observations become frequent enough to significantly interfere with natural events. Assessments of juvenile mortality, however, have often been based on sampling intervals ranging from weeks (Table 1; see also Muus 1973, Keough \& Downes 1982, Grosberg 1988, Qian \& Chia 1994) to months (Table 1; see also Denley \& Underwood 1979, Osman 1987, Keough 1989) or even up to a year (Table 1). Low sampling frequencies have the additional disadvantage of providing a greater window for other processes to alter juvenile densities and thereby confound mortality estimates: net immigration or the establishment of new juveniles cause an underestimation of mortality, whereas net emigration leads to an overestimation of juvenile mortality. Longer intervals also provide more time for early juveniles to become established, die, and disappear before being recorded (Minchinton \& Scheibling 1993, Gosselin \& Qian 1996). For example, the thin shells of early juvenile Macoma balthica, a soft-sediment bivalve, can completely dissolve within only $5 \mathrm{~d}$ after the individual's death (Elmgren et al. 1986). As a rule of thumb, the most reliable way of quantifying juvenile mortality is to monitor the fate of individuals from the onset of independent benthic life, using sampling intervals $\leq 1 \mathrm{~d}$.

The various methods used to quantify juvenile mortality in the field differ considerably in the level of resolution they can achieve. The 4 methods most com- monly used to quantify natural rates of juvenile mortality are examined below. Tethering techniques, which have serious drawbacks for quantifying natural mortality (Barshaw \& Able 1990, Barbeau \& Scheibling 1994, Peterson \& Black 1994, Zimmer-Faust et al. 1994), are not reviewed herein.

\section{Mapping}

The mapping technique consists of manually recording the positions, usually on flexible transparent plastic sheets, of all sessile individuals within a given area, noting whether they are dead or alive, and repeating the procedure at regular intervals. The major advantage of the method is that it allows the observer to monitor all individuals, including those hidden by surface irregularities or by other organisms, and to directly verify the identity and status of each individual, which is not always possible with imaging techniques. Although searching and mapping are time consuming, this is nevertheless the most reliable way of quantifying juvenile mortality of sessile organisms attached to flat or slightly irregular surfaces.

\section{Imaging}

Photography is the most commonly used imaging technique, although video recording has also been suggested for monitoring juveniles (Wright et al. 1991). Close-up images of benthic substrata provide a permanent record of sessile organisms that can subsequently be analyzed with digital or image analyzers. Images constitute a record of size, shape, and distribution of the juveniles, as well as characteristics of their immediate environment, that may help establish the causes of mortality. The images are 2-dimensional, however, and therefore individuais hidden by surface irregularities will not be detected. Larger individuals are recorded more clearly, and consequently there is potential for underestimating the arrival and mortality of small, new juveniles. Imaging techniques are most appropriate when the juveniles are well-spaced and easily identified, when weather and substratum conditions do not interfere with the clarity of the images, and when the resolution of the images is sufficient to detect even (and especially) the smallest recruits.

\section{Mark and recapture}

When mapping or imaging techniques cannot be used, as is the case with motile individuals, mark and recapture may be the only way to monitor animals over 
time and associate their fate with elements of their history (e.g. initial location, age, body size, lineage). The simplest approach to mark and recapture is to simultaneously label many early juveniles, for instance by staining (Levin 1990, Qian \& Chia 1994) or by painting external hard structures such as gastropod shells (Boulding \& Van Alstyne 1993). The fate of individuals, however, cannot be determined if all receive the same label. Individualized marks have been applied to small juveniles with hard external structures (Gosselin 1993) but have yet to be used to determine natural mortality rates in the field. A comparable method used in 2 studies of sessile animals (Table 1) consists of marking the substratum near each individual to enable relocation on subsequent inspections. In motile species, recapture is complicated by the small size, dispersal, cryptic distribution, and short persistence time of dead bodies of most early juveniles. Consequently, the fate of missing individuals can be uncertain. Since handling and marking can have deleterious or beneficial effects on survival, a preliminary study should be done to quantify the effects of the method. Mark and recapture promises to be useful for short-term studies of motile juveniles with limited dispersal if marking can be accomplished without excessive disturbance to the organisms.

\section{Cohort monitoring}

It is not always possible to repeatedly monitor a given set of individuals over time. An alternative is to sample the population at intervals without attempting to relocate the same individuals. In such cases, the unit being monitored is the cohort rather than the individual, and decreases in density over time are interpreted as mortality. Cohort monitoring has been the most commonly used method of studying juvenile mortality (17 of 30 studies). In its simplest form, cohort monitoring consists of 2 samplings, once before and once after a given interval (Spight 1975, Osman et al. 1989, McShane 1991). Such 'snap-shot' evaluations are simple and demand relatively little time, but are sensitive to atypical events and provide no information on the variability of mortality over time. A more commonly used approach is based on histogram analysis and consists of the establishment of size- or age-frequency distributions for a time series of samples. When cohorts overlap, size measurements are necessary to distinguish cohorts by graphical or mathematical procedures (modal analysis: Macdonald \& Pitcher 1979, Fournier \& Breen 1983, Grant et al. 1987).

Since individual organisms are not monitored over time, searching and handling are reduced and habitats are not disturbed prior to sampling. There are impor- tant limitations, however, to cohort monitoring techniques. The arrival of new juveniles is not always in sufficiently discrete pulses to monitor distinct cohorts, or sample sizes required for cohort analysis can be unfeasibly large (Grant et al. 1987). In addition, migration, settlement, or hatching of new juveniles during the study will interfere with mortality determinations unless these processes are also quantified. Migration can be substantial even among early juveniles generally thought to have limited motility (e.g. Emerson \& Grant 1991, Martel \& Chia 1991a, b). Cohort studies are generally not effective for measuring mortality during the potentially critical first days of early juvenile life because it is rarely possible to distinguish between cohorts on a very short time scale (e.g. daily cohorts). Nevertheless, cohort monitoring may be the only way of obtaining mortality estimates for highly motile juveniles or where sampling excessively disturbs the organism and its environment, as can be the case for infaunal juveniles.

In conclusion, mapping is the most reliable way of quantifying mortality through the early juvenile period, although estimates from photographic records can be satisfactory under appropriate conditions. Both methods, however, are only applicable to sessile organisms. No study has yet monitored the fate of individual early juveniles of motile species in the field. This situation might be partly resolved by improving marking techniques to mark and recapture juveniles with limited dispersal. Data obtained by monitoring cohorts rather than individuals can be used as rough estimates of early juvenile mortality but generally do not reveal the precise timing or intensity of mortality and cannot be used to accurately describe changes in mortality rate over periods of a few days or less. Since the biological significance of mortality data is highly dependent on the method, sampling frequency, and age of study organisms, reports should include detailed information on the methodology as well as the age of the juveniles when they first appear in the samples. Future reports should also provide untransformed mortality data to facilitate comparisons with other published results.

\section{CAUSES OF EARLY JUVENILE MORTALITY}

The data compiled herein (Fig. 1) show that juvenile mortality is highest early in juvenile life. In addition, the processes operating early in the juvenile period, including those regulating mortality, differ from those operating at any other time of life (Gosselin 1994). This suggests that mortality factors specific to the early juvenile phase may be important determinants of population parameters as well as driving forces in the evo- 
lutionary development of the species. This section aims to identify all factors reported as causes or potential causes of early juvenile mortality as a first step towards characterizing the selective pressures operating during this period of life. To date, 5 biotic factors (predation, competition, energy depletion, disease, developmental complication) and 5 abiotic factors (desiccation, temperature, salinity, water motion, solar radiation) have been suggested as causes of early juvenile mortality.

\section{Biotic factors}

Predation, including cannibalism (Hines et al. 1990, Fernandez et al. 1993a) and ingestion or crushing by grazers ('bulldozing'; Connell 1961a, Dayton 1971), is often assumed to be the single most important cause of early juvenile mortality (Thorson 1966, Spight 1976, Keough \& Downes 1982, Stoner 1990, Hurlbut 1991a, b, Fernandez et al. 1993b). Early juveniles are indeed vulnerable to predation and may be killed in great numbers if exposed to predators, as shown in bivalves (Thorson 1966, Elmgren et al. 1986, Pohle et al. 1991), gastropods (Gosselin \& Chia 1995a, b, Ray \& Stoner 1995), decapod crustaceans (Smith \& Herrnkind 1992, Barshaw et al. 1994), echinoderms (Highsmith 1982), and ascidians (Young \& Chia 1984, Osman et al. 1990, 1992, Osman \& Whitlach 1995). Decapod crustacean predators are often identified as a major source of predation on early juveniles (Thorson 1966, Möller \& Rosenberg 1983, MacKenzie et al. 1985, Ojeda \& Dearborn 1991, Guillou \& Tartu 1994, Gosselin \& Chia 1995a). The potentially large impact of decapods results from their generally high abundances, broad distribution in both intertidal and subtidal habitats, high motility, their ability to crush protective structures, and their need to process large amounts of food. Juvenile invertebrates may nevertheless be consumed by predators from a broad spectrum of taxa. The impact of pelagic predators, particularly fish, is rarely examined but could be substantial (e.g. Ojeda \& Dearborn 1991, Wahle \& Steneck 1992, Fernandez et al. 1993b).

Competition for space by undercutting, overgrowth, or aggressive contacts among sessile organisms can be a direct cause of early juvenile mortality, and can involve inter- or intraspecific interactions (ascidians, Young \& Chia 1984, Davis 1987; barnacles, Hatton 1938, Connell 1961a, b, Denley \& Underwood 1979). Competition for space can also be an indirect cause of mortality: at high densities, many juveniles of the limpet Patella cochlear were located on the shells of adults, and high mortality occurred when they attempted to make the transition from shell to rock surface (Branch 1974, 1975a). These interactions are most frequent when recruitment is intense and growth rates are high, therefore leading to density-dependent mortality (Connell 1961a, 1985). Competition for space should be a minor cause of death among juveniles in many populations that do not experience densitydependent mortality

Competition for food can lead to reduced early juvenile growth (oysters, Zajac et al 1989; oysters and ascidians, Osman et al. 1990; amphipods, Hill 1992) but there is only equivocal evidence that it causes early juvenile mortality in the field foysters, Osman et al. 1989, Zajac et al. 1989; snails, Branch \& Branch 1980; amphipods, Hill 1992). Laboratory studies have shown that food availability to early juveniles can affect their growth and survival (oysters, Zajac et al 1989; abalone, McBride 1990; snails, Gosselin \& Chia 1994), but there is no evidence yet that food is limiting for early juveniles in the field.

Survival through the first days of juvenile life can also depend on the amount of energy reserves remaining after metamorphosis, since feeding in some species is initially insufficient to meet the needs of the early juvenile foysters, Whyte et al. 1992). Feeding by early juveniles may be delayed or assimilation of food may be incomplete due to a transition in metabolism (clams, Guillou \& Tartu 1994). Early juvenile survival might therefore be dependent on the amount of energy accumulated during the larval phase or remaining from the initial content of the egg. There is in fact considerable variation in duration of survival without food during the early juvenile period. Newly hatched Nucella emarginata, a muricid snail, can survive 50 to $120 \mathrm{~d}$ of starvation (Gosselin \& Chia 1994), while hatchling Oceanebra sp. (Luckens 1970) and Urosalpinx cinerea (Rittschof et al. 1983), also muricids, survive a week or less without food. The importance of energy depletion as a cause of early mortality may therefore vary substantially among species.

Diseases have caused high mortality in late juvenile seastars Acanthaster planci (Zann et al. 1987) and in juvenile oysters $\leq 25 \mathrm{~mm}$ (Davis \& Barber 1994). Blooms of toxic dinoflagellates also kill juvenile oysters (Luckenbach et al. 1993). Generally, however, little is known of the prevalence of diseases and parasites or of the impact of toxic phytoplankton on juveniles. The ephemeral nature of remains of dead early juveniles, largely due to their rapid invasion by protozoans and bacteria, render positive identification of these factors difficult. These factors may nevertheless be important, and a better understanding of their contribution to early juvenile mortality is needed.

In many species, a considerable reorganization of the body occurs at metamorphosis (e.g. see Chia \& Burke 1978). During this process, developmental complications that are genetically determined or induced 
by environmental conditions such as temperature extremes, salinity extremes, or ultraviolet radiation might produce dysfunctional juveniles. Physiological defects have been proposed as possible causes of mortality in cases where traditional biotic and abiotic mortality factors could not account for early juvenile mortality (MacKenzie 1981, Gosselin \& Chia 1995a, Roegner \& Mann 1995, Gosselin \& Qian 1996).

\section{Abiotic factors}

While predation is the most documented cause of mortality, abiotic factors might be locally more important, as in intertidal habitats where conditions fluctuate to extremes over just a few hours, or in bays and estuaries where seasonal changes in physical conditions are amplified by freshwater runoff and greater thermal fluctuations relative to the open ocean.

Early juveniles inhabiting the intertidal zone, when emersed, can lose water much faster than adults because of the greater surface-to-volume ratio of small individuals (Foster 1971, Wolcott 1973). Early juveniles are consequently much more vulnerable to desiccation stress than adults (barnacles, Foster 1971; limpets, Davies 1969, Wolcott 1973, Branch 1975b; snails, Gosselin \& Chia 1995a). Early juvenile mortality in the field has been attributed to desiccation in barnacles (Denley \& Underwood 1979), limpets (Wolcott 1973, Branch 1975b, Lewis \& Bowman 1975) and snails (Behrens 1972).

Thermal tolerance is also lower in early juveniles than in adults (Kinne 1970, Gosselin \& Chia 1995a), but field temperatures are reported to be within early juvenile tolerance limits (crabs, Brown et al. 1992; limpets, Wolcott 1973; snails, Gosselin \& Chia 1995a; seastars, Chen \& Chen 1993). For instance, the occurrence of temperature extremes over a 3 yr period did not correspond to increased levels of mortality in the bivalve Cerastoderma edule (Guillou \& Tartu 1994). It is not clear, however, whether thermal tolerance limits of early juveniles are exceeded in tropical and polar climates, since most studies to date have examined organisms from temperate habitats. In addition, suboptimal temperatures may be indirectly responsible for early juvenile mortality by aggravating the effects of other factors such as reduced salinity and desiccation (Wolcott 1973, Gosselin \& Chia 1995a).

Persistent low salinity levels cause early juvenile mortality in crabs (Brown et al. 1992, Brown \& Bert 1993), snails (Berry \& Hunt 1980), urchins (Himmelman et al. 1984), and seastars (Chen \& Chen 1993). Nevertheless, short-term reductions in salinity (e.g. during a low tide) were not lethal to early juvenile limpets (Wolcott 1973) or snails (Berry \& Hunt 1980), and tolerance limits of early juveniles have in some cases been found to exceed the range of conditions occurring in the natural habitat (crabs, Brown et al. 1992; seastars, Chen \& Chen 1993). Low salinity becomes a greater threat to early juveniles when combined with suboptimal temperatures (Berry \& Hunt 1980, Brown et al. 1992, Brown \& Bert 1993, Chen \& Chen 1993).

Water motion can cause early juvenile mortality in a variety of ways. For instance, mortality can be caused by the transport and deposition of sand (abalone, Schiel 1993) or silt (ascidians, Young \& Chia 1984) on early juveniles. Recently settled barnacles can also be killed as a result of scouring by waterborne material (Connell 1961a) or dislodgement by algal fronds moving with the waves ('algal whiplash', Lewis 1964, Hawkins 1983). However, dislodgement of non-sessile animals by wave action (Behrens 1972, Sarver 1979, Gosselin \& Chia 1995a) should not simply be equated with death. Indeed, most early juveniles sink very slowly due to their large surface-to-volume ratio and, in several bivalve and gastropod species, to the release of a thin mucous thread which allows them to reattach or drift until they encounter a favorable habitat (Sigurdsson et al. 1976, Vahl 1983, Martel \& Chia 1991a, b, Armonies 1992, 1994).

Solar radiation, particularly the ultraviolet component, can cause mortality in encapsulated gastropod larvae developing in intertidal (Rawlings 1996) and shallow subtidal habitats (Biermann et al. 1992) and in planktonic larvae in coral reef-waters (Gleason \& Wellington 1995). Exposure to natural UV radiation can also cause rapid mortality in postlarval phases of a variety of 'shade-loving' species, including bryozoans and ascidians (age and size not specified, Jokiel 1980). Among animals with protective shells, tubes or pigmentation, the less-protected early juveniles may be highly vulnerable (Jokiel 1980). The actual effects of solar radiation on early juveniles have yet to be determined.

In conclusion, the available information suggests that desiccation (intertidal habitats) and predation are widespread and may often be the most important causes of early juvenile mortality. Their importance as selective pressures is supported by studies indicating a close association of early juveniles with structurally complex microhabitats (Bayne 1964, Sarver 1979, Wahle \& Steneck 1991, Smith \& Herrnkind 1992, Sandt \& Stoner 1993, Gosselin \& Chia 1995b) which constitute refuges from these factors (Gosselin \& Chia 1995b). However, some early juveniles remain exposed to predators and desiccation throughout juvenile life, particularly juveniles of sessile species. This suggests either that predation and desiccation have not been important selective pressures on early juve- 
niles of these species or that other solutions have been found (e.g. physiological or chemical defenses): in both cases, other factors may presently be responsible for more mortality than are predation or desiccation. At present, however, there is insufficient information on the occurrence of most other factors or on the frequency of exposure of early juveniles to determine their relative importance as causes of death. Factors such as solar radiation, diseases, and 'internal' causes (energy depletion, physiological defects appearing during metamorphosis) may have a significant effect on survival in some populations.

\section{IMPLICATIONS OF JUVENILE MORTALITY}

\section{Population parameters}

The high levels of early juvenile mortality reported in Table 1 are clearly sufficient to cause profound transformations of cohorts. Small variations in early juvenile mortality should therefore have significant repercussions on population size. Field studies have shown that early juvenile mortality does indeed have a determining effect on benthic population parameters (Connell 1985, Osman et al. 1990, 1992, Osman \& Whitlach 1995, Roegner \& Mann 1995). Mortality during the early juvenile period has been shown to regulate population size (lobsters, Smith \& Herrnkind 1992; polychaetes, Qian \& Chia 1994; crabs, Eggleston \& Armstrong 1995; oysters, Roegner \& Mann 1995) and distribution (hydroids, Yund et al. 1987; nudibranchs, Sarver 1979; barnacles, Connell 1985; urchins, Rowley 1989; abalones, McShane 1991; oysters, Roegner \& Mann 1995), Even among benthic macroalgae, colonization of free space can largely depend on the survival of a few individuals through an early postsettlement period (cf. review by Vadas et al. 1992). In addition, early juvenile mortality can have a determining effect on community composition (Osman et al. 1992, Olafsson et al. 1994, Osman \& Whitlach 1995).

Although cohorts generally sustain heavy losses during the larval period, mortality during the early juvenile phase can exceed larval mortality. In the ascidian Diplosoma similis, for instance, mortality during the brief planktonic larval period, lasting $\leq 15$ min, was $29 \%$ whereas mortality during the first day following settlement was $50 \%$ (Stoner 1990). The processes involved in early juvenile mortality can also be at least as important as larval processes (dispersal, mortality, settlement) in determining the distribution and abundance of adults (urchins, Rowley 1989; abalone, McShane 1991; ascidians, Osman et al. 1992; polychaetes, Qian \& Chia 1994).
Any event that would influence the number of individuals surviving to the end of this early period would thus have a greater effect on survival to first reproduction than comparable events in later periods of life, a conclusion also reached by Osman (1987) for the vermetid Serpulorbis squamigerus. A trait that would enhance early juvenile survivorship even slightly should therefore be more strongly favoured than a trait producing a similar enhancement of survival at later stages of life. In evolutionary terms, early juvenile traits should be more dynamic and responsive to environmental change than traits occurring later in life.

\section{Age at maturity}

One postulate of life history theory is that demographic pressures, including juvenile mortality, are a major evolutionary determinant of age at maturity (Bell 1980, Stearns \& Koella 1986, Stearns 1992). If age at maturity is reduced, fewer individuals may die before reaching maturity. When increased survivorship to maturity due to earlier maturation outweighs the physiological and developmental costs (cf. Stearns 1992) of this change, then earlier maturation is favoured. Although age at maturity can be influenced by a variety of factors, such as growth rate, fecundity, and developmental, phylogenetic and environmental constraints (Roff 1984, Stearns \& Koella 1986, Stearns 1992, Hutchings 1993), the timing and magnitude of juvenile mortality are nevertheless believed to be major determinants of age at maturity.

Some life history models regarding age at maturity assume that, after the larval period, a constant proportion of the population dies in each time unit (Roff 1984, Stearns 1992), and that mortality rates reach low, stable levels only at maturity (but see Stearns \& Koella 1986). The data reviewed herein indicate these assumptions often do not hold among benthic marine invertebrates. Instead, survivorship decreases exponentially in most species during an initial period lasting up to $\sim 4$ mo (Fig. 1). The selective pressure exerted by juvenile mortality is therefore highly age dependent, being most intense during a brief initial period, rather than constant or linearly decreasing as a function of age.

Demographic pressure favouring a change in age at maturity will be greatest when a small change in age at maturity produces a large change in number of individuals surviving to maturity. Using a generalized survivorship curve (Fig. 2) patterned on Fig. 1, we observe that a reduction in age at maturity during a period of high mortality, from an age $\alpha$ to $\alpha-1$, could lead to a substantial increase in number of individuals reaching 


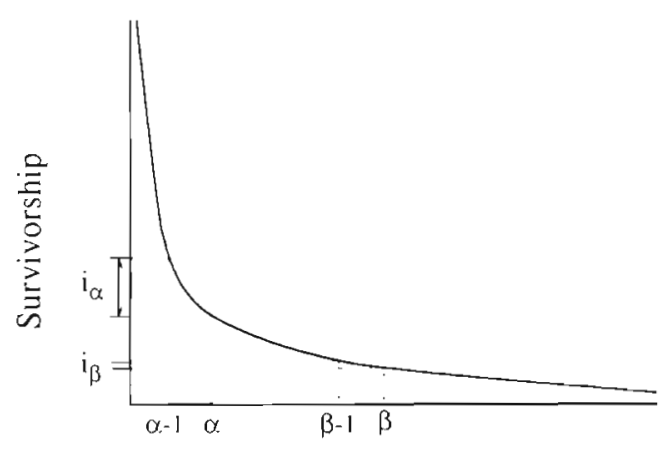

Age (postlarval)

Fig. 2. Implications for age at maturity of a survivorship curve with an initial period of exponential decrease. This generalized model of age-specific survivorship is based on data shown in Fig. 1 A reduction in age at maturity in a species maturing during the exponential phase (e.g. from $\alpha$ to $\alpha-1$ ) is shown to result in a greater increase $\left(i_{\alpha}\right\}$ in survival to maturity than an equal change (e.g. from $\beta$ to $\beta-1$ ) in a species maturing after the exponential phase

maturity $\left(i_{\alpha}\right)$. A similar reduction in age at maturity from a later age $\beta$ to $\beta-1$ would result in a much smaller increase $\left(i_{\beta}\right)$ in survival to maturity. Given the pattern of mortality described in Fig. 1, juvenile mortality is likely to have little influence on age at maturity in species maturing beyond the age of 4 mo since mortality then remains low. However, species maturing earlier might experience much stronger selection in favour of an earlier age at maturity. Juvenile mortality would therefore have a more restricted influence on age at maturity than had been postulated. Juvenile mortality may be a major determinant of age at maturity only in species maturing within $\sim 4 \mathrm{mo}$, whereas in late maturing species juvenile mortality may play a minor role, if at all. Age at maturity among early and late maturing species could thus be largely controlled by different factors.

The postulate that juvenile mortality is a determinant of age at maturity has not been verified with empirical data for benthic marine invertebrates. We therefore collated published data on age at first reproduction for 92 species of benthic marine invertebrates distributed among 6 phyla (Appendix 1). Significantly, benthic marine invertebrates were largely partitioned into 2 groups (Fig. 3A); $21.7 \%$ of these species matured within $45 \mathrm{~d}$ after beginning juvenile life, whereas $59.8 \%$ matured after at least 1 yr. With the exception of a modest peak at $6 \mathrm{mo}$, frequencies of age at first reproduction beyond the first 4 mo remained low up to the age of 12 mo (Fig $3 \mathrm{~A}$ ). The influence of juvenile mortality on age at maturity is expected to differ substantially among these 2 groups and, as a result, the timing of age at maturity in the 2 groups could be largely controlled by different selective pressures.
If the pattern of juvenile mortality is a major determinant of age at maturity among species maturing within $\sim 4$ mo of juvenile life, then the distribution of ages at maturity within this period should be skewed towards early ages. Frequencies of age at first reproduction among age classes $\leq 4$ mo (Fig. 3B) were indeed skewed towards younger age classes. Twenty species began to reproduce before or at the age of $45 \mathrm{~d}$, but only $6 \mathrm{did}$ so during the following $75 \mathrm{~d}$ (i.e. to the

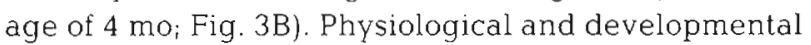
constraints would ultimately set the minimum limit for age at maturity, resulting in the observed clustering of species within the first weeks of postlarval life, with frequencies peaking at 15 to $30 \mathrm{~d}$ (Fig. 3B). Unfortunately, the direct relationship of survivorship as a function of age at first reproduction could not be determined because there were few species for which both parameters had been fully documented. Nevertheless, these age at first reproduction results are consistent with the hypothesis that juvenile mortality has influenced age at maturity in species maturing within $-4 \mathrm{mo}$.
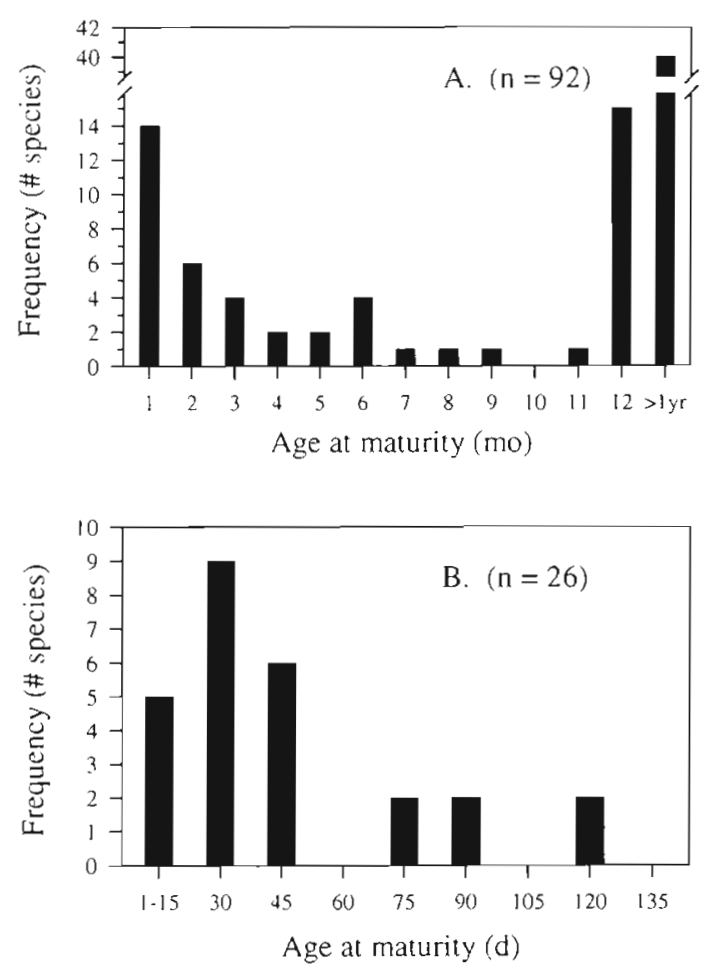

Fig. 3. Frequency distribution of age at first reproduction among benthic marine invertebrates, as obtained from published reports (data and sources listed in Appendix 1). Age represents the time elapsed since the onset of juvenile life, and thus does not include the egg-to-juvenile period. (A) All species pooled with $30 \mathrm{~d}$ intervals. (B) Species with age at maturity $\leq 135 \mathrm{~d}$ pooled with $15 \mathrm{~d}$ intervals 


\section{CONCLUSION}

Heavy mortality during the larval phase has often been used as an argument to justify or encourage larval biology studies because the processes at work during the larval phase should play an important role in the evolution of the species. The same argument can also be made for the early juvenile phase. High early juvenile mortality is widespread among benthic marine invertebrates. We suggest that extreme vulnerability at the onset of juvenile life to a range of mortality factors is a shared trait that is largely responsible for the common pattern of exponential decrease in survivorship during juvenile life. Natural variation within this pattern, however, would be largely a consequence of variation in intensity of mortality factors. A better understanding of the sources of variation of early juvenile mortality will undoubtedly help resolve the problematic link (cf. Ólafsson et al. 1994) between larval abundance and recruitment to the adult segment of the population.
Although selective pressures specifically operating early in juvenile life may influence the evolutionary development of age at maturity, the effect of juvenile mortality is likely to be limited to species maturing within $\sim 4$ mo and will therefore not be equal or directly comparable among all species. Our limited knowledge of juvenile mortality factors, which precludes a ranking of factors as causes of mortality, may be the most important obstacle to progress in understanding the adaptive and evolutionary significance of juvenile and life history traits.

Acknowledgements. We thank the participants of the 7 th International Congress on Invertebrate Reproduction at Santa Cruz who provided comments on a presentation of the material contained in this paper. We also thank. D. Rittschof and 3 anonymous reviewers for comments on an earlier version of the manuscript. This study was supported by 2 DAG grants from HKUST to P.Y.Q. L.A.G. was supported by a postdoctoral fellowship from the Department of Biology, HKUST, and DAG grants to P.Y.Q.

Appendix 1. Age at first reproduction of 92 species of benthic marine invertebrates. Age is defined here as starting at the onset of juvenile life

\begin{tabular}{|c|c|c|}
\hline Taxa & Age at first reproduction & Source \\
\hline \multicolumn{3}{|l|}{ ANNELIDA, POLYCHAETA } \\
\hline Dinophilus gyrociliatus & $<11 \mathrm{~d}^{\mathrm{d}}$ & Akesson \& Costlow (1991) \\
\hline Ophryotrocha diadema & $-13 d^{d}$ & Akesson $(1976)$ \\
\hline Pseudopolydora kempi japonıca & $2 w k$ & Miyohara (1979) \\
\hline Ophryotrocha maculata & $-24-29 d^{a}$ & Äkesson (1973) \\
\hline Ophryotrocha puerilis & $-28 d^{d}$ & Akesson (1967) \\
\hline Romanchella pustulata & $40-50 \mathrm{~d}$ & Canete \& Ambler (1990) \\
\hline Armandia brevis & $6 w k$ & Hermans (1966) \\
\hline Capitella sp. I & $67.1 \mathrm{~d}^{d}$ & Bridges et al. (1994) \\
\hline Streblospio benedicti & $78.9 \mathrm{~d}^{\mathrm{d}}$ & Bridges et al. (1994) \\
\hline Kinbergonuphis simoni & $5-10 \mathrm{mo}^{\mathrm{d}}$ & Hsieh \& Simon (1991) \\
\hline Typosyllis pulchra & $6-9 \mathrm{mo}^{a}$ & Heacox (1980) \\
\hline Eteone longa & $1 \mathrm{yr}$ & Rasmussen (1973) \\
\hline Nereis vexillosa & In 2 nd yr & Roe $(1975)$ \\
\hline Melinna palmata & $2 y r$ & Grehan (1991) \\
\hline \multicolumn{3}{|l|}{ MOLLUSCA, POLYPLACOPHORA } \\
\hline Lepidochitona fernaldi & $\sim 6 \mathrm{mo}^{\mathrm{d}}$ & Eernisse (1984) \\
\hline Mopalia mucosa & In 2 nd yr & Heath (1907) \\
\hline Onithochiton quercinus & 2 yr & Otway (1994) \\
\hline Plaxiphora albida & $2 y r$ & Otway (1994) \\
\hline \multicolumn{3}{|l|}{ MOLLUSCA, BIVALVIA } \\
\hline Mytilus trossulus & & \\
\hline (published as $M$. edulis) & $1-2 \mathrm{mo}$ & Suchanek $\{1981\}$ \\
\hline Spisula solidissima & $3 \mathrm{mo}^{\mathrm{t}}$ & Chintala \& Grassle (1995) \\
\hline Bankia setacea & $4 \mathrm{mo}$ & Quayle $(1955,1959)$ \\
\hline Mytilus californianus & $4-8 \mathrm{mo}$ & Suchanek (1981) \\
\hline Lasaea subviridis & $6-8 \mathrm{mo}^{\mathrm{a}}$ & Strathmann (1987) \\
\hline Tapes philippinarum & $-1 y r$ & Holland \& Chew (1974) \\
\hline Albra tenuis & $1 \mathrm{yr}$ & Bachelet (1989) \\
\hline Idas argenteus & $1 \mathrm{yr}$ & Dean (1993) \\
\hline Crassostrea virginica & $1-2$ yr & Galtsoff (1964) \\
\hline Calyptogena magnufica & $1-4 y r$ & Kennish \& Lutz (1992) \\
\hline
\end{tabular}


Appendix 1 (continued)

\begin{tabular}{|c|c|c|}
\hline Taxa & Age at first reproduction & Source \\
\hline \multicolumn{3}{|c|}{ MOLLUSCA, BIVALVIA (continued) } \\
\hline Cerastoderma edule & $1.5 \mathrm{yr}$ & Seed \& Brown (1977) \\
\hline Lithophaga lithophaga & $2+y r$ & Galinou-Mitsoudi \& Sinis (1994) \\
\hline Nitidotellina nitidula & $2 y r$ & Kawai et al. (1993) \\
\hline Phacosoma japonicum & $2-5 y^{\mathrm{c}}$ & Sato (1994) \\
\hline Tresus nuttallii & 3 yr & Campbell et al. (1990) \\
\hline Tresus capax & $3-4$ yr & Bourne \& Smith (1972) \\
\hline Panope abrupta & $3 / 4 \mathrm{yr}^{\mathrm{d}}$ & Andersen (1971) \\
\hline Modiolus modiolus & $4-6$ yr & Seed \& Brown (1977) \\
\hline Chlamys islandica & $4-9$ yr & Pedersen (1994) \\
\hline Arctica islandica & $7 \mathrm{yr}$ & Rowell et al. (1990) \\
\hline \multicolumn{3}{|c|}{ MOLLUSCA, GASTROPODA } \\
\hline Alderia modesta & $10 \mathrm{~d}$ & Seeleman (1967) \\
\hline Olea hansineensis & $2-3 w k$ & Chia \& Skeel (1973) \\
\hline Phestilla sibogae & $20 \mathrm{~d}$ & Miller \& Hadfield (1990) \\
\hline Doridella steinbergae & $3-4 w k$ & Strathmann (1987) \\
\hline Eubranchus rustyus & $3-5 w k$ & Robilliard (1971) \\
\hline Stylocheilus longicauda & $27 \mathrm{~d}^{\mathrm{a}}$ & Switzer-Dunlap \& Hadfield (1979) \\
\hline Aplysia juliana & $35-45 d^{a}$ & Hadfield \& Switzer-Dunlap (1990) \\
\hline Aplysia dactylomeda & $66 \mathrm{~d}^{\mathrm{d}}$ & Switzer-Dunlap \& Hadfield (1979) \\
\hline Littorina sp. & $-140 \mathrm{~d}^{3}$ & Boulding \& Van Alstyne (1993) \\
\hline Dolabella auricularia & $180-294 \mathrm{~d}^{\mathrm{d}}$ & Switzer-Dunlap \& Hadfield (1979) \\
\hline Lacuna vincta & $\sim 7 \mathrm{mo}$ & Smith (1973) \\
\hline Lacuna pallidula & $-8 \mathrm{mo}$ & Smith (1973) \\
\hline Littorina littorea & $8.5 \mathrm{mo}^{\mathrm{e}}$ & Hughes \& Roberts (1980) \\
\hline Tritonia diomedea & $277 d^{4}$ & Kempf \& Willows (1977) \\
\hline Lottia digitalis & $\sim 1$ yг & Choat \& Black (1979) \\
\hline Retusa obtusa & $\sim 1 \mathrm{yr}$ & Berry $(1989)$ \\
\hline Umbonium costatum & 1 ys & Noda et al. (1995) \\
\hline Umbonium vestiarium & -1 yr & Berry (1989) \\
\hline Bembicium vittatum & $1 \mathrm{yr}$ & Black et al. (1994) \\
\hline Trichotropsis cancellata & $1 \mathrm{yr}$ & Yonge $(1962)$ \\
\hline Nucella emarginata & $1 \mathrm{yr}$ & Spight (1982) \\
\hline Littorina nigrolineata & $18 \mathrm{mo}^{2}$ & Hughes \& Roberts (1980) \\
\hline Littorina rudis & $18 \mathrm{mo}^{\mathrm{e}}$ & Hughes \& Roberts (1980) \\
\hline Nerita atramentosa & $20 \mathrm{mo}$ & Underwood (1975) \\
\hline Nucella canaliculata & $2-3$ yr & Spight (1975) \\
\hline Nucella lapillus & $2-3$ yr & Crothers (1985) \\
\hline Drupella cornus & $2.5-3.5 \mathrm{yr}$ & Black \& Johnson (1994) \\
\hline Littorina neritoides & $3 \mathrm{yr}^{\mathrm{e}}$ & Hughes \& Roberts (1980) \\
\hline Haliotis discus hannai & $3 \mathrm{yr}$ & Sakai (1962) \\
\hline Haliotis la vigata & -3 yr & Shepherd \& Laws (1974) \\
\hline Haliotis ruber & $-3-4 \mathrm{yr}$ & Shepherd \& Laws (1974) \\
\hline Haliotis ins & $-3-4$ yr & Poore (1973) \\
\hline Strombus gigas & $3.2-3.3 \mathrm{yr}$ & Appeldoorn (1990) \\
\hline Philine gibba & $3.75 \mathrm{yr}$ & Seager (1983) \\
\hline Haliotis tuberculata & $\sim 4 \mathrm{yr}$ & Poore (1973) \\
\hline Nucella lamellosa & 4 yr & Spight (1975) \\
\hline Buccinum undatum & $4-7 \mathrm{yr}$ & Gendron (1992) \\
\hline Busycon carica & $9 \mathrm{yr}^{\circ}$ & Castagna \& Kraeuter (1994) \\
\hline \multicolumn{3}{|c|}{ ARTHROPODA, CRUSTACEA } \\
\hline Chthamalus fissus & $3 w k$ & Page (1984) \\
\hline Chthamalus anisopoma & $42 \mathrm{~d}$ & Lively (1986) \\
\hline Semibalanus balanoides & $11 \mathrm{mo}$ & Connell (1985) \\
\hline Pollicipes polymerus & $100-175 \mathrm{~d}$ & Page $(1986)$ \\
\hline Dorhynchus thomsoni & $1-2$ yr & Hartnoll \& Rice (1985) \\
\hline Tetraclita squamosa & $-2 y r$ & Hines (1978) \\
\hline \multicolumn{3}{|c|}{ UROCHORDATA, ASCIDIACEA } \\
\hline Botryllus schlosseri & $25-70 \mathrm{~d}$ & Grosberg (1988) \\
\hline Didemnum candidum & $6-8 w k$ & Hurlbut (1991a) \\
\hline
\end{tabular}


Appendix 1 (continued)

\begin{tabular}{|c|c|c|}
\hline Taxa & Age at first reproduction & Source \\
\hline \multicolumn{3}{|l|}{ BRYOZOA. } \\
\hline Bugula neritina & $-35 d$ & Keough (1986) \\
\hline \multicolumn{3}{|l|}{ ECHINODERMATA } \\
\hline Strongylocentrotus purpuratus & $2 y r$ & Gonor (1972) \\
\hline Strongylocentrotus droebachiensis & $2-3$ yr & Munk (1992) \\
\hline Centrostephanus rodgersii & $-3 \mathrm{yr}$ & King et al. (1994) \\
\hline Cucumaria pseudocurata & $-3 y \mathrm{r}$ & Rutherford (1973) \\
\hline Amphiura filiformis & $3 y г$ & Muus (1981) \\
\hline Amphiura chiajej & $\sim 4 \mathrm{yr}$ & Munday \& Keegan (1992) \\
\hline Pisaster ochraceus & $5 \mathrm{yr}$ & Menge (1974) \\
\hline \multicolumn{3}{|c|}{$\begin{array}{l}\text { ¿Data obtained from laboratory reared individuals } \\
\text { 'Spisula solidissima was previously reported to mature after } 1-4 \text { yr (Ropes 1979, Sephton \& Bryan 1990) } \\
\text { "Range of ages at maturity corresponds to site-specific differences } \\
\text { 'Data for male / female } \\
\text { e Mean age at maturity }\end{array}$} \\
\hline
\end{tabular}

\section{LITERATURE CITED}

Akesson B (1967) On the biology and larval morphology of Ophryotrocha puerilis Claparède \& Metschnikov (Polychaeta). Ophelia 4:111-119

Akesson B (1973) Morphology and life-history of Ophryotrocha maculata sp. n (Polychaeta, Dorvilleidae). Zool Scr $2: 141-144$

Akesson B (1976) Morphology and life cycle of Ophryotrocha diadema, a new polychaete species from California. Ophelia 15:23-35

A.kesson B, Costlow JD (1991) Effects of constant and cyclic temperatures at different salinity levels on survival and reproduction in Dinophilus gyrociliatus (Polychaeta: Dinophilidae). Bull Mar Sci 48:485-499

Andersen AM Jr (1971) Spawning, growth, and spatial distribution of the geoduck clam, Panope generosa Gould, in Hood Canal, Washington. PhD dissertation, University of Washington, Seattle

Appeldoorn RS (1990) Growth of juvenile queen conch, Strombus gigas Linnaeus, 1758, off La Parguera, Puerto Rico. J Shellfish Res 9:59-62

Armonies W (1992) Migratory rhythms of drifting juvenile molluscs in tidal waters of the Wadden Sea. Mar Ecol Prog Ser 83:197-206

Armonies W (1994) Turnover of postlarval bivalves in sediments of tidal flats in Konigshafen (German Wadden Sea). Helgol Meeresunt 48:291-297

Bachelet G (1989) Recruitment in Albra tenuis (Montagu) (Bivalvia, Semelidae), a species with direct development and a protracted meiobenthic phase. In: Ryland JS, Tyler PA (eds) Proc 23rd Eur Mar Biol Symp. Olsen and Olsen, Fredensborg, Denmark, p 23-30

Bachelet G, Yacine-Kassab M (1987) Intégration de la phase post-recrutée dans la dynamique des populations du gastéropode intertidal Hydrobia ulvae (Pennant). J Exp Mar Biol Ecol 111:37-60

Barbeau MA, Scheibling RE (1994) Procedural effects of prey tethering experiments - predation of juvenile scallops by crabs and seastars. Mar Ecol Prog Ser 111:305-310

Barshaw DE, Able KW (1990) Tethering as a technique for assessing predation rates in different habitats: an evaluation using juvenile lobsters, Homarus americanus. Fish Bull US 88:415-417

Barshaw DE, Able KW, Heck KL Jr (1994) Salt marsh peat reefs as protection for post-larval lobsters Homarus americanus from fish and crab predators: comparisons with other substrates. Mar Ecol Prog Ser 106:203-206

Bayne BL (1964) Primary and secondary settlement in Mytilus edulis L. (Mollusca). J Anim Ecol 33:513-523

Behrens S (1972) The role of wave impact and desiccation on the distribution of Littorina sitkana Philippi, 1845. Veliger 15:129-132

Bell G (1980) The costs of reproduction and their consequences. Am Nat 116:45-76

Berry AJ (1989) Factors implicated in the timing of breeding in two contrasted annual intertidal gastropods, Retusa obtusa (Montagu) and Umbonium vestiarium (L.). In: Ryland JS, Tyler PA (eds) Proc 23rd Eur Mar Biol Symp. Olsen \& Olsen, Fredensborg, Denmark, p 31-36

Berry AJ, Hunt DC (1980) Behaviour and tolerance of salinity and temperature in new-born Littorina rudis (Maton) and the range of the species in the Forth Estuary. J Molluscan Stud 46:55-65

Biermann CH, Schinner GO, Strathmann RR (1992) Influence of solar radiation, microalgal fouling, and current on deposition site and survival of embryos of a dorid nudibranch gastropod. Mar Ecol Prog Ser 86:205-215

Black R, Johnson MS (1994) Growth rates in outbreak populations of the corallivorous gastropod Drupella cornus (Roding 1798) at Ningaloo Reef, Western Australia. Coral Reefs 13:145-150

Black R, Turner SJ, Johnson MS (1994) The early life history of Bembicium vittatum Philippi, 1846 (Gastropoda: Littorinidae). Veliger 37:393-399

Boulding EG, Van Alstyne KL (1993) Mechanisms of differential survival and growth of two species of Littorina on wave-exposed and on protected shores. J Exp Mar Biol Ecol 169:139-166

Bourne N, Smith DW (1972) Breeding and growth of the horse clam Tresus capax (Gould), in southern British Columbia. Proc Natl Shellfish Ass 62:38-46 
Branch GM (1974) The ecology of Patella Linnaeus from the Cape Peninsula, South Africa. III. Growth rates. Trans R Soc S Afr 41:161-193

Branch GM (1975a) Intraspecific competition in Patella cochlear Born. J Anim Ecol 44:263-282

Branch GM (1975b) Ecology of Patella species from the Cape Peninsula, South Africa. IV. Desiccation. Mar Biol 32 $179-188$

Branch GM, Branch ML (1980) Competition in Bembicium auratum (Gastropoda) and its effect on microalgal standing stock in mangrove muds. Oecologia 46:106-114

Bridges TS, Levin LA, Cabrera D, Plaia G (1994) Effects of sediment amended with sewage, algae, or hydrocarbons on growth and reproduction in two opportunistic polychaetes. J Exp Mar Biol Ecol 177:99-119

Brown SD, Bert TM (1993) The effects of temperature and salinity on molting and survival of Menippe adina and $M$. mercenaria (Crustacea, Decapoda) postsettlement juveniles. Mar Ecol Prog Ser 99:41-49

Brown SD, Bert TM, Tweedale WA, Torres JJ, Lindberg WJ (1992) The effects of temperature and salinity on survival and development of early life stage Florida stone crabs Menippe mercenaria (Say). J Exp Mar Biol Ecol 157 $115-136$

Campbell A, Bourne N, Carolsfeld W (1990) Growth and size at maturity of the Pacific gaper Tresus nuttallii (Conrad 1837) in southern British Columbia. J Shellfish Res 9 $273-278$

Canete JI, Ambler RP (1990) Growth and age determination in the spirorbid polychaete Romanchella pustulata Knight-Jones, 1978. Rev Biol Mar 25:147-164

Castagna M, Kraeuter JN (1994) Age, growth rate, sexual dimorphism and fecundity of knobbed whelk Busycon carica (Gmelin, 1791) in a western Mid-Atlantic lagoon system, Virginia. J Shellfish Res 13:581-585

Chen CP, Chen BY (1993) The effect of temperature-salinity combinations on survival and growth of juvenile Patiriella pseudoexigua (Echinodermata: Asteroidea). Mar Biol 115 $119-122$

Chia FS, Burke RD (1978) Echinoderm metamorphosis: fate of larval structures. In: Chia FS, Rice ME (eds) Settlement and metamorphosis of marine invertebrate larvae. Elsevier/North-Holland Biomedical Press, New York

Chia FS, Skeel M (1973) The effects of food consumption on growth, fecundity and mortality in a sacoglossan opisthobranch, Olea hansineensis. Veliger 16:153-158

Chintala MM, Grassle JP (1995) Early gametogenesis and spawning in 'juvenile' Atlantic surfclams, Spisula solidissima (Dillwyn, 1819). J Shellfish Res 14:301-306

Choat JH, Black R (1979) Life histories of limpets and the limpet-laminarian relationship. J Exp Mar Biol Ecol 41: $25-50$

Cobb JS, Wahle RA (1994) Early-life history and recruitment processes of clawed lobsters. Crustaceana 67:1-25

Connell JH (1961a) Effects of competition, predation by Thais lapillus, and other factors on natural populations of the barnacle Balanus balanoides. Ecol Monogr 31:61-104

Connell JH (1961b) The influence of interspecific competition and other factors on the distribution of the barnacle Chthamalus stellatus. Ecology 42:710-723

Connell JH (1985) The consequences of variation in initial settlement vs. post-settlement mortality in rocky intertidal communities. J Exp Mar Biol Ecol 93:11-45

Crothers JH (1985) Dog-whelks: an introduction to the biology of Nucella lapillus (L.). Field Stud 6:291-360

Davies PS (1969) Physiological ecology of Patella. III. Desiccation effects. J Mar Biol Ass UK 49:291-304
Davis AR (1987) Variation in recruitment of the subtidal colonial ascidian Podoclavella cylindrica (Quoy \& Gaimard): the role of substratum choice and early survival. J Exp Mar Biol Ecol 106:57-71

Davis CV, Barber BJ (1994) Size-dependent mortality in hatchery-reared populations of oysters, Crassostrea virginica, Gmelin 1791, affected by juvenile oyster disease. J Shellfish Res 13:137-142

Dayton PK (1971) Competition, disturbance, and community organization: the provision and subsequent utilization of space in a rocky intertidal community. Ecol Monogr 41: $351-389$

Dean HK (1993) A population study of the bivalve Idas argenteus Jeffreys, 1876, (Bivalvia: Mytilidae) recovered from a submerged wood block in the deep North Atlantic ocean. Malacologia 35:21-41

Denley EJ, Underwood AJ (1979) Experiments on factors influencing settlement, survival, and growth of two species of barnacles in New South Wales. J Exp Mar Biol Ecol. $36: 269-293$

Eernisse DJ (1984) Lepidochitona (Gray 1821) (Mollusca: Polyplacophora) from the Pacific Coast of the United States: systematics and reproduction. PhD dissertation, University of California, Santa Cruz

Eggleston DB, Armstrong DA (1995) Pre- and post-settlement determinants of estuarine dungeness $\mathrm{crab}$ recruitment. Ecol Monogr 65:193-216

Elmgren R, Ankar S, Marteleur G (1986) Adult interference with postlarvae in soft sediments: the Pontoporeia-Macoma example. Ecology 67:827-836

Emerson CW, Grant J (1991) The control of soft-shell clam (Mya arenaria) recruitment on intertidal sandflats by bedload sediment transport. Limnol Oceanogr 36:1288-1300

Faller-Fritsch RJ, Emson RH (1986) Causes and patterns of mortality in Littorina rudis (Maton) in relation to intraspecific variation: a review. In: Moore PG, Seed R (eds) The ecology of rocky coasts. Essays presented to J.R. Lewis. Columbia University Press, New York, p 157-177

Feare CJ (1970) Aspects of the ecology of an exposed shore population of dogwhelks Nucella lapillus (L.). Oecologia 5 $1-18$

Fernandez M, Armstrong D, Iribarne O (1993a) First cohort of young-of-the-year dungeness crab, Cancer magister, reduces abundance of subsequent cohorts in intertidal shell habitat. Can J Fish Aquat Sci 50:2100-2105

Fernandez M, Iribarne O, Armstrong D (1993b) Habitat selection by young-of-the-year Dungeness crab Cancer magister and predation risk in intertidal habitats. Mar Ecol Prog Ser 92:171-177

Foster BA (1971) Desiccation as a factor in the intertidal zonation of barnacles. Mar Biol 8:12-29

Fournier DA, Breen PA (1983) Estimation of abalone mortality rates with growth analysis. Trans Am Fish Soc 112: 403-411

Galtsoff PS (1964) The American oyster Crassostrea virginica Gmelin. US Fish Bull Wild Serv Fish 64

Galinou-Mitsoudi S, Sinis AI (1994) Reproductive cycle and fecundity of the date mussel Lithophaga lithophaga (Bivalvia: Mytilidae). J Molluscan Stud 60:371-385

Gendron L (1992) Determination of the size at sexual maturity of the waved whelk Buccinum undatum Linnaeus, 1758, in the Gulf of St. Lawrence, as a basis for the establishment of a minimum catchable size. J Shellfish Res 11:1-7

Gleason DF, Wellington GM (1995) Variation in UVB sensitivity of planula larvae of the coral Agaricia agaricites along a depth gradient. Mar Biol 123:693-703

Gonor JJ (1972) Gonad growth in the sea urchin, Strongylo- 
centrotus purpuratus (Stimpson) (Echinodermata: Echinoidea) and the assumptions of gonad index methods. J Exp Mar Biol Ecol 10:89-103

Gosselin LA (1993) A method for marking small juvenile gastropods. J Mar Biol Ass UK 73:963-966

Gosselin LA (1994) The ecology of early juvenile Nucella emarginata (Gastropoda, Prosobranchia): Are hatchling snails simply small adults? PhD dissertation, University of Alberta, Edmonton

Gosselin LA, Chia FS (1994) Feeding habits of newly hatched juveniles of an intertidal predatory gastropod, Nucella emarginata (Deshayes). J Exp Mar Biol Ecol 176:1-13

Gosselin LA, Chia FS (1995a) Characterizing temperate rocky shores from the perspective of an early juvenile snail: the main threats to survival of newly hatched Nucella emarginata. Mar Biol 122:625-635

Gosselin LA, Chia FS (1995b) Distribution and dispersal of early juvenile snails: effectiveness of intertidal microhabitats as refuges and food sources. Mar Ecol Prog Ser 128: $213-223$

Gosselin LA, Qian PY (1996) Early postsettlement mortality of an intertidal barnacle: a critical period for survival. Mar Ecol Prog Ser 135:69-75

Grant A, Morgan PJ, Olive PJW (1987) Use made in marine ecology of methods for estimating demographic patterns from size/frequency data. Mar Biol 95:201-208

Grehan AJ (1991) Demography and reproductive biology of Melinna palmata (Ampharetidae: Polychaeta) in inner Galway Bay on the west coast of Ireland. Mar Biol 109: $459-468$

Grosberg RK (1988) Life-history variation within a population of the colonial ascidian Botryllus schlosseri. I. The genetic and environmental control of seasonal variation. Evolution 42:900-920

Guillou J, Tartu C (1994) Post-larval and juvenile mortality in a population of the edible cockle Cerastoderma edule (L.) from Northern Brittany. Neth J Sea Res 33:103-111

Hadfield MG, Switzer-Dunlap MF (1990) Environmental regulation of lifespan and reproduction in Aplysia juliana. Adv Invert Reprod 5:247-255

Hartnoll RG, Rice AL (1985) Further studies on the biology of the deep-sea spider crab Dorhynchus thomsoni: instar sequence and the annual cycle. In: Gibbs PE (ed) Proc 19th Eur Mar Biol Symp. Cambridge University Press, Cambridge, p 231-241

Hatton H (1938) Essais de bionomie explicative sur quelques espèces intercotidales d'algues et d'animaux. Ann Inst Oceanogr 17:241-348

Hawkins SJ (1983) Interactions of Patella and macroalgae with settling Semibalanus balanoides (L.). J Exp Mar Biol Ecol 71:55-72

Heacox AE (1980) Reproduction and larval development of Typosyllis pulchra (Berkeley \& Berkeley) (Polychaeta: Syllidae). Pac Sci 34:245-259

Heath $H$ (1907) The gonad in certain chitons. Zool Anz 32: $10-12$

Hermans CO (1966) The natural history and larval anatomy of Armandia brevis (Polychaeta: Opheliidae). PhD dissertation, University of Washington, Seattle

Highsmith RC (1982) Induced settlement and metamorphosis of sand dollar (Dendraster excentricus) larvae in predatorfree sites: adult sand dollar beds. Ecology 63:329-337

Hill C (1992) Interactions between year classes in the benthic amphipod Monoporeia affinis: effects on juvenile survival and growth. Oecologia 91:157-162

Himmelman JH, Guderley H, Vignault G, Drouin G (1984) Response of the sea urchin, Strongylocentrotus droe- bachiensis, to reduced salinities: importance of size, acclimation, and interpopulation differences. Can J Zool 62: $1015-1021$

Hines AH (1978) Reproduction in three species of intertidal barnacles from central California. Biol Bull (Woods Hole) 154:262-281

Hines A. Haddon M, Wiechert L (1990) Guild structure and foraging impact of blue crabs and epibenthic fish in a subestuary of Chesapeake Bay. Mar Ecol Prog Ser 67: $105-126$

Holland DA, Chew KK (1974) Reproductive cycle of the Manilla clam (Venerupis japonica) from Hood Canal, Washington. Proc Natl Shellfish Ass 64:53-58

Hsieh HL, Simon JL (1991) Life history and population dynamics of Kinbergonuphis simoni (Polychaeta: Onuphidae). Mar Biol 110:117-125

Hughes RN, Roberts DJ (1980) Reproductive effort of winkles (Littorina spp.) with contrasted methods of reproduction. Oecologia 47:130-136

Hurlbut CJ (1991a) The effects of larval abundance, settlement and juvenile mortality on the depth distribution of a colonial ascidian. J Exp Mar Biol Ecol 150:183-202

Hurlbut CJ (1991b) Community recruitment: settlement and juvenile survival of seven co-occurring species of sessile marine invertebrates. Mar Biol 109:507-515

Hutchings JA (1993) Adaptive life histories effected by agespecific survival and growth rate. Ecology 74:673-684

Jokiel PL (1980) Solar ultraviolet radiation and coral reef epifauna. Science 207:1069-1071

Kawai K, Goshima S, Nakao S (1993) Reproductive cycle and shell growth of the tellin Nitidotellina nitidula (Dunker) in Hakodate Bay. Bull Fac Fish Hokkaido Univ 44:105-115

Kempf SC, Willows AOD (1977) Laboratory culture of the nudibranch Tritonia diomedea Bergh (Tritoniidae: Opisthobranchial and some aspects of its behavioral development. J Exp Mar Biol Ecol 30:261-276

Kennish MJ, Lutz RA (1992) The hydrothermal vent clam, Calyptogena magnifica (Boss and Tumer, 1980): a review of existing literature. Rev Aquat Sci 6:29-66

Keough MJ (1986) The distribution of a bryozoan on seagrass blades: settlement, growth, and mortality. Ecology 67. $846-857$

Keough MJ (1989) Dispersal of the bryozoan Bugula neritina and effects of adults on newly metamorphosed juveniles. Mar Ecol Prog Ser 57:163-171

Keough MJ, Downes BJ (1982) Recruitment of marine invertebrates: the role of active larval choices and early mortality. Oecologia $54: 348-352$

King CK, Hoegh-Guldberg O, Byrne M (1994) Reproductive cycle of Centrostephanus rodgersii (Echinoidea), with recommendations for the establishment of a sea urchin fishery in New South Wales. Mar Biol 120:95-106

Kinne $O(1970)$ Temperature. In: Kinne $O$ (ed) Marine ecology, Vol I, Part 1 Wiley-Interscience, New York, p $321-514$

Levin LA (1990) A review of methods for labelling and tracking marine invertebrate larvae. Ophelia 32:115-144

Lewis JR (1964) The ecology of racky shores. English University Press Ltd, London

Lewis JR, Bowman RS (1975) Local habitat-induced variations in the population dynamics of Patella vulgata L. J Exp Mar Biol Ecol 17:165-204

Lively CM (1986) Competition, comparative life histories, and maintenance of shell morphology in a barnacle. Ecology $67: 858-864$

Luckenbach MW, Sellner KG. Shumway SE, Greene K (1993) Effects of two bloom-forming dinoflagellates, Prorocen- 
trum minium and Gyrodinium uncatenum, on the growth and survival of the eastern oyster, Crassostrea virginica (Gmelin 1791). J Shellfish Res 12:411-415

Luckens PA (1970) Predation and intertidal zonation at Asamushi. Bull Mar Biol Stn Asamushi 14:33-53

Macdonald PDM, Pitcher IJ (1979) Age-groups from size-frequency data: a versatile and efficient method of analysing distribution mixtures. J Fish Res Bd Can 36:987-1001

MacKenzie CL. Jr (1981) Improving survival of seed oysters. In: Webster D (ed) Oyster culture in Maryland, 1980. UMSG-MAP-81-01. Maryland Sea Grant Press, College Park, p 33-41

MacKenzie CL Jr, Radosh DJ, Reid RN (1985) Densities, growth, and mortalities of juveniles of the surf clam (Spisula solidissima) (Dillwyn) in the New York Bight. J Shellfish Res 5:81-84

Martel A. Chia FS (1991a) Drifting and dispersal of small bivalves and gastropods with direct development. J Exp Mar Biol Ecol 150:131-147

Martel A, Chia FS (1991b) Foot-raising behaviour and active participation during the initial phase of post-metamorphic drifting in the gastropod Lacuna spp. Mar Ecol Prog Ser $72: 247-254$

McBride SC (1990) The relative effects of diet and irradiance on the growth and survival of post-larval red abalone, Haliotis rufescens. MSc thesis, San Jose State University. San Jose, California

MCShane PE (1991) Density-dependent mortality of recruits of the abalone Haliotis rubra (Mollusca: Gastropoda). Mar Biol 110:385-389

McShane PE, Naylor JR (1995) Depth can affect post-settlement survival of Haliotis iris (Mollusca: Gastropoda). J Exp Mar Biol Ecol 187:1-12

Menge BA (1974) Effect of wave action and competition on brooding and reproductive effort in the sea star, Leptasterias hexactis. Ecology 55:84-93

Miller SE, Hadfield MG (1990) Developmental arrest during larval life and life-span extension in a marine mollusc Science 248:356-358

Minchinton TE, Scheibling RE (1993) Variations in sampling procedure and frequency affect estimates of recruitment of barnacles. Mar Ecol Prog Ser 99:83-88

Miyohara M (1979) Reproduction and development of Pseudopolydora kempi japonica (Polychaeta: Spionidae). with special reference to the polar lobe formation. J Fac Sci Hokkaido Univ, Ser 6 (Zoology) 21:355-364

Möller P, Rosenberg R (1983) Recruitment, abundance and production of Mya arenaria and Cardium edule in marine shallow water, western Sweden. Ophelia 22:33-55

Munday BW, Keegan BF (1992) Population dynamics of Amphiura chiajei (Echinodermata: Ophiuroidea) in Killary Harbour, on the west coast of Ireland. Mar Biol 114: $595-605$

Munk JE (1992) Reproduction and growth of green urchins Strongylocentrotus droebachiensis (Mueller) near Kodiak, Alaska. J Shellfish Res 11:245-254

Muus K (1973) Settling, growth and mortality of young bivalves in the Øresund. Ophelia 12:79-116

Muus K (1981) Density and growth of juvenile Amphiura filiformis (Ophiuroidea) in the Øresund. Ophelia 20:153-168

Noda T, Nakao S, Goshuma S (1995) Life history of the temperate subtidal gastropod Umbonium costatum. Mar Biol $122: 73-78$

Ojeda FP, Dearborn JH (1991) Feeding ecology of benthic mobile predators: experimental analyses of their influence in rocky subtidal communities of the Gulf of Maine. J Exp Mar Biol Ecol 149:13-44
Olafsson EB, Peterson CH, Ambrose WG Jr (1994) Does recruitment limitation structure populations and communities of macro-invertebrates in marine soft-sediments: the relative significance of pre- and post-settlement processes. Oceanogr Mar Biol Ann Rev 32:65-109

Osman RW (1987) Interactions between the vermetid Serpulorbis squamigerus (Carpenter) and several species of encrusting bryozoans. J Exp Mar Biol Ecol 111:267-284

Osman RW, Whitlach RB (1995) Predation on early ontogenetic life stages and its effect on recruitment into a marine epifaunal community. Mar Ecol Prog Ser 117:111-126

Osman RW, Whitlach RB, Malatesta RJ (1992) Potential role of micro-predators in determining recruitment into a marine community. Mar Ecol Prog Ser 83:35-43

Osman RW, Whitlach RB, Malatesta RJ, Zajac RN (1990) Ontogenetic changes in trophic relationships and their effects on recruitment. In: Barnes $M$, Gibson RN (eds) Trophic relationships in the marine environment. Aberdeen University Press, Aberdeen, p 117-129

Osman RW, Whitlach RB, Zajac RN (1989) Effects of resident species on recruitment into a community: larval settlement versus post-settlement mortality in the oyster Crassostrea virginica. Mar Ecol Prog Ser 54:61-73

Otway NM (1994) Population ecology of the low-shore chitons Onithochiton quercinus and Plaxiphora albida. Mar Biol 121:105-116

Page HM (1984) Local variation in reproductive patterns of two species of intertidal barnacles, Pollicipes polymerus Sowerby and Chthamalus fissus Darwin. J Exp Mar Biol Ecol 74:259-272

Page HM (1986) Differences in population structure and growth rate of the stalked barnacle Pollicipes polymerus between a rocky headland and an offshore oil platform. Mar Ecol Prog Ser 29:157-164

Pedersen SA (1994) Population parameters of the Iceland scallop (Chlamys islandica (Muller)) from West Greenland. J Northwest Atl Fish Sci 16:75-87

Peterson CH, Black R (1994) An experimentalist's challenge when artifacts of intervention interact with treatments Mar Ecol Prog Ser 111:289-297

Pohle DG, Bricelj VM, Garcia-Esquivel Z (1991) The eelgrass canopy: an above-bottom refuge from benthic predators for juvenile bay scallops Argopecten irradians. Mar Ecol Prog Ser 74:47-59

Poore GCB (1973) Ecology of New Zealand abalones, Haliotis species (Mollusca: Gastropoda). NZ J Mar Freshwat Res 7 . $67-84$

Qian PY, Chia FS (1994) In situ measurement of recruitment. mortality, growth, and fecundity of Capitella sp. (Annelida: Polychaeta). Mar Ecol Prog Ser 111:53-62

Quayle DB (1955) The British Columbia shipworm. Rep BC Dept Fish (1955):92-104

Quayle DB (1959) The growth rate of Bankia setacea Tryon. In: Ray DL (ed) Marine boring and fouling organisms. University of Washington Press, Seattle, p 175-185

Raimondi PT (1990) Patterns, mechanisms, consequences of variability in settlement and recruitment of an intertidal barnacle. Ecol Monogr 60:283-309

Rasmussen E (1973) Systematics and ecology of the Isefjord marine fauna (Denmark). Ophelia 1:1-507

Rawlings TA (1996) Shields against ultraviolet radiation: an additional protective role for the egg capsules of benthic marine gastropods. Mar Ecol Prog Ser 136:81-95

Ray M, Stoner AW (1995) Growth, survivorship, and habitat choice in a newly settled seagrass gastropod, Strombus gigas. Mar Ecol Prog Ser 123:83-94

Rittschof D, Williams LG, Brown B, Carriker MR (1983) 
Chemical attraction of newly hatched oyster drills. Biol Bull (Woods Hole) 164:493-505

Robilliard GA (1971) Range extensions of some Northeast Pacific nudibranchs (Mollusca: Gastropoda: Opisthobranchia) to Washington and British Columbia, with notes on their biology. Veliger 14:162-165

Roe P (1975) Aspects of life history and territorial behaviour in young individuals of Platynereis bicaniliculata and Nereis vexillosa (Annelida, Polychaeta). Pac Sci 29:341-348

Roegner GC, Mann R (1995) Early recruitment and growth of the American oyster Crassostrea virginica (Bivalvia: Ostreidae) with respect to tidal zonation and season. Mar Ecol Prog Ser 117:91-101

Roff DA (1984) The evolution of life history parameters in teleosts. Can J Fish Aquat Sci 41:989-1000

Ropes JW (1979) Shell length at sexual maturity of surf clams, Spisula solidissima, from an inshore habitat. Proc Natl Shellfish Ass 69: 85-91

Rowell TW, Chaisson DR, McLane JT (1990) Size and age of sexual maturity and annual gamelogenetic cycle in the ocean quahog, Arctica islandica (Linnaeus, 1767), from coastal waters in Nova Scotia, Canada. J Shellfish Res 9: $195-204$

Rowley RJ (1989) Settlement and recruitment of sea urchins (Strongylocentrotus spp.) in a sea-urchin barren ground and a kelp bed: are populations regulated by settlement or post-settlement processes? Mar Biol 100:485-494

Rowley RJ (1990) Newly settled sea urchins in a kelp bed and urchin barren ground: a comparison of growth and mortality. Mar Ecol Prog Ser 62:229-240

Rutherford JC (1973) Reproduction, growth and mortality of the holothurian Cucumaria pseudocurata. Mar Biol 22: $167-176$

Sakai S (1962) Ecological studies on the abalone, Haliotis discus hannai Ino-IV. Studies on the growth. Bull Jap Soc Sci Fish 28:899-904

Sandt VJ, Stoner AW (1993) Ontogenetic shift in habitat by early juvenile queen conch, Strombus gigas: patterns and potential mechanisms. Fish Bull US 91:516-525

Sarver DJ (1979) Recruitment and juvenile survival in the sea hare Aplysia juliana (Gastropoda: Opisthobranchia). Mar Biol 54:353-361

Sato S (1994) Analysis of the relationship between growth and sexual maturation in Phacosoma japonicum (Bivalvia: Veneridae). Mar Biol 118:663-672

Schiel DR (1993) Experimental evaluation of commercialscale enhancement of abalone Haliotis iris populations in New Zealand. Mar Ecol Prog Ser 97:167-181

Seager JR (1983) Population dynamics of the antarctic opisthobranch Philine gibba Strebel. J Exp Mar Biol Ecol 60:163-179

Sebens KP, Lewis JR (1985) Rare events and population structure of the barnacle Semibalanus cariosus (Pallas, 1788). J Exp Mar Biol Ecol 87:55-65

Seed R, Brown RA (1977) A comparison of the reproductive cycles of Modiolus modiolus (L.). Cerastoderma (=Cardium) edule (L.), and Mytilus edulis L. in Strangford Lough, Northern Ireland. Oecologia 30:173-188

Seeleman U (1967) Rearing experiments on the amphibian slug Alderia modesta. Helgol Meeresunters 20:576-593

Sephton TW. Bryan CF (1990) Age and growth rate determinations for the Atlantic surf clam, Spisula solidissima (Dillwyn, 1817), in Prince Edward Island, Canada. J Shellfish Res 9:177-186

Sewell MA, Watson JC (1993) A 'source' for asteroid larvae?: recruitment of Pisaster ochraceus, Pycnopodia helianthoides and Dermasterias imbricata in Nootka Sound.
British Columbia. Mar Biol 117:387-398

Shepherd SA, Laws HM (1974) Studies on southern Australian abalone (Genus Haliotis). II. Reproduction of five species. Aust J Mar Freshwat Res 25:49-62

Sigurdsson JB, Titman CW, Davies PA (1976) The dispersal of young post-larval bivalve molluscs by byssus threads. Nature 262:386-387

Smith DAS (1973) The population biology of Lacuna pallidula (Da Costa) and Lacuna vincta (Montagu) in North-East England. J Mar Biol Ass UK 53:493-520

Smith KN, Herrnkind WF (1992) Predation on early juvenile spiny lobsters Panulirus argus (Latreille): influence of size and shelter.J Exp Mar Biol Ecol 157:3-18

Southgate T (1982) A comparative study of Lacuna vincta and Lacuna pallidula (Gastropoda: Prosobranchia) in littoral algal turfs. J Molluscan Stud 48:302-309

Spight TM (1975) On a snail's chances of becoming a year old. Oikos 26:9-14

Spight TM (1976) Ecology of hatching size for marine snails. Oecologia 24:283-294

Spight TM (1982) Population sizes of two marine snals with a changing food supply. J Exp Mar Biol Ecol 57:195-217

Stearns SC (1992) The evolution of life histories. Oxford University Press, Oxford

Stearns SC, Koella JC (1986) The evolution of phenotypic plasticity in life-history traits: predictions of reaction norms for age and size at maturity. Evolution 40:893-913

Stoner DS (1990) Recruitment of a tropical colonial ascidian: relative importance of pre-settlement vs. post-settlement processes. Ecology 71:1682-1690

Strathmann MF (1987) Reproduction and development of marine invertebrates of the Northern Pacific coast. University of Washington Press, Seattle

Suchanek TH (1981) The role of disturbance in the evolution of life history strategies in the intertidal mussels Mytilus edulis and Mytilus californianus. Oecologia 50:143-152

Sutherland JP (1990) Recruitment regulates demographic variation in a tropical intertidal barnacle. Ecology 71 955-972

Switzer-Dunlap M, Hadfield MG (1979) Reproductive patterns of Hawaiian aplysiid gastropods. In: Stancyk SE (ed) Reproductive ecology of marine invertebrates. University of South Carolina Press, Columbia, p 199-210

Thorson G (1966) Some factors influencing the recruitment and establishment of marine benthic communities. Neth $J$ Sea Res 3:267-293

Underwood AJ (1975) Comparative studies on the biology of Nerita atramentosa Reeve, Bembicium nanum (Lamarck) and Cellana tramoserica (Sowerby) (Gastropoda: Prosobranchia) in S.E. Australia. J Exp Mar Biol Ecol 18: $153-172$

Vadas RL, Johnson S, Norton TA (1992) Recruitment and mortality of early post-settlement stages of benthic algae. Br Phycol J 27:331-351

Vahl O (1983) Mucus drifting in the limpet Helcion (=Patina) pellucidus (Prosobranchia, Patellidae). Sarsia 68:209-211

Wahle RA, Steneck RS (1991) Recruitment habitats and nursery grounds of the American lobster Homarus americanus: a demographic bottleneck? Mar Ecol Prog Ser 69:231-243

Wahle RA, Steneck RS (1992) Habitat restrictions in early benthic life: experiments on habitat selection and in situ predation with the American lobster. J Exp Mar Biol Ecol 157:91-114

Werner EE, Gilliam JF (1984) The ontogenetic niche and species interactions in size-structured populations. Ann Rev Ecol Syst 15:393-425

Wethey DS (1984) Spatial pattern in barnacle settlement: day 
to day changes during the settlement season. J Mar Biol Ass UK 64:687-698

Whyte JNC, Bourne N, Ginther NG, Hodgson CA (1992) Compositional changes in the larva to juvenile development of the scallop Crassadoma gigantea (Gray). J Exp Mar Biol Ecol 163:13-29

Wolcott TG (1973) Physiological ecology and intertidal zonation in limpets (Acmaea): a critical look at 'limiting factors' Biol Bull (Woods Hole) 145:389-422

Wright M, Bakus GJ, Ortiz A, Ormsby B, Barnes DM (1991) Computer image processing and automatic counting and measuring of fouling organisms. Comp Biol Med 21. $173-180$

Yonge CM (1962) On the biology of the mesogastropod Trichotropsis cancellata Hinds, a benthic indicator species. Biol Bull (Woods Hole) 122:160-181

Young BL (1991) Spartina axil zones: preferred settlement sites of barnacles. J Exp Mar Biol Ecol 151:71-82

This review was submitted to the editor
Young CM, Chia FS (1984) Microhabitat-associated variability in survival and growth of subtidal solitary ascidians during the first 21 days after settlement. Mar Biol 81 : $61-68$

Yund PO, Cunningham CW, Buss LW (1987) Recruitment and postrecruitment interactions in a colonial hydroid. Ecology 68:971-982

Zajac RN, Whitlatch RB, Osman RW (1989) Effects of interspecific density and food supply on survivorship and growth of newly settled benthos. Mar Ecol Prog Ser 56: $127-132$

Zann L, Brodie J, Berryman C, Naqasima M (1987) Recruitment, ecology, growth and behaviour of juvenile Acanthaster planci (L.) (Echinodermata: Asteroidea). Bull Mar Sci 41:561-575

Zimmer-Faust RK, Fielder DR, Heck KL, Coen LD, Morgan SG (1994) Effects of tethering on predatory escape by juvenile blue crabs. Mar Ecol Prog Ser 111:299-303

Manuscript first received. December 12, 1995

Revised version accepted: November 11, 1996 